\title{
Humic acids from vermicompost positively influence the nutrient uptake in mangosteen seedlings ${ }^{1}$
}

\author{
Gedeon Almeida Gomes Júnior², Rafaela Alves Pereira ${ }^{2}$, \\ George Andrade Sodré2, Eduardo Gross ${ }^{2}$
}

\section{ABSTRACT}

The application of growth promoting substances, such as humic acids, during the formation of fruit seedlings can benefit growth and increase the plant nutrient uptake and translocation. This study aimed to evaluate the effect of the application of humic acid doses $\left(0 \mathrm{mg} \mathrm{L}^{-1}, 2 \mathrm{mg} \mathrm{L}^{-1}, 20 \mathrm{mg} \mathrm{L}^{-1}\right.$, $40 \mathrm{mg} \mathrm{L}^{-1}$ and $\left.200 \mathrm{mg} \mathrm{L}^{-1}\right)$ extracted from vermicompost of sugarcane filter cake on the nutrient uptake of seminal mangosteen (Garcinia mangostana L.) seedlings. The experimental design was completely randomized, with 7 replicates for each treatment. The application of humic acids promoted curvilinear increments with quadratic rates for $\mathrm{N}$, $\mathrm{P}, \mathrm{K}, \mathrm{Ca}, \mathrm{Mg}$ and $\mathrm{S}$ contents from shoots and roots, as well as quadratic increments in the $\mathrm{Zn}$ and $\mathrm{Mn}$ uptake by shoots. The application of humic acids increased the chlorophyll a and chlorophyll $\mathrm{b}$ contents and reduced the carotenoid content. Overall, the regression analysis demonstrated that a dose of $150 \mathrm{mg} \mathrm{L}^{-1}$ is capable of providing the most adequate nutrient uptake by plants, and should be recommended for the production of mangosteen seedlings. Humic acids from vermicompost can provide a better nutrition in mangosteen seedlings at the nursery stage.

KEYWORDS: Garcinia mangostana L., humic substances, plant nutrition.

\section{INTRODUCTION}

Mangosteen (Garcinia mangostana L.) is a fruit species that, in Brazil, is distributed in the Amazon region and in southern Bahia state, where there is a predominance of hot and humid climate and satisfactory rainfall distribution during the year. The fruits have excellent conditions for commercial exploitation, with high prices in the domestic and foreign markets (Sacramento et al. 2007, Carvalho 2014).

\section{RESUMO}

Ácidos húmicos de vermicomposto influenciam positivamente na absorção de nutrientes em mudas de mangostanzeiro

A aplicação de substâncias promotoras de crescimento, a exemplo dos ácidos húmicos, no desenvolvimento de mudas frutíferas pode beneficiar o crescimento e potencializar a absorção e translocação de nutrientes na planta. Objetivou-se avaliar o efeito da aplicação de doses de ácidos húmicos $\left(0 \mathrm{mg} \mathrm{L}^{-1}\right.$; $\left.2 \mathrm{mg} \mathrm{L}^{-1} ; 20 \mathrm{mg} \mathrm{L}^{-1} ; 40 \mathrm{mg} \mathrm{L}^{-1} ; 200 \mathrm{mg} \mathrm{L}^{-1}\right)$ extraídos de vermicomposto de torta de filtro de cana-de-açúcar na absorção de nutrientes de mudas seminais de mangostanzeiro (Garcinia mangostana L.). O delineamento experimental foi inteiramente casualizado, com 7 repetições para cada tratamento. A aplicação dos ácidos húmicos promoveu incrementos com taxas quadráticas para o conteúdo de $\mathrm{N}, \mathrm{P}, \mathrm{K}, \mathrm{Ca}, \mathrm{Mg}$ e S da parte aérea e raiz, bem como incrementos de natureza quadrática no teor dos nutrientes $\mathrm{Zn}$ e Mn na parte aérea. A aplicação de ácidos húmicos elevou os teores de clorofila a e clorofila b e reduziu o teor de carotenoides. De forma geral, a análise de regressão demonstrou que uma dose $150 \mathrm{mg} \mathrm{L}^{-1}$ é capaz de proporcionar a absorção de nutrientes mais adequada pelas plantas, e deve ser recomendada para a produção de mudas de mangostanzeiro. Ácidos húmicos de vermicomposto podem propiciar uma nutrição mais adequada a mudas de mangostanzeiro em fase de viveiro.

PALAVRAS-CHAVE: Garcinia mangostana L., substâncias húmicas, nutrição de plantas.

Its propagation in commercial crops occurs mainly by seeds and, in this species, the seed formation occurs by apomixia. The root system of mangosteen plants is characterized by low secondary roots and low nutrient uptake capacity during the nursery stage. This characteristic can be pointed out as the main reason for the prolonged seedling formation time, which usually occurs in 2 years (Sacramento et al. 2009, Carvalho 2014).

The plant growth promotion by bioactive fractions of organic matter, such as humic acids, 
can be a viable alternative for nutrient uptake in mangosteen seedlings and, consequently, reduces the period under greenhouse conditions. Some studies have documented positive and promising results of the application of these substances on the nutrient uptake of plant species (Baldotto et al. 2009, Lima et al. 2011, Busato et al. 2016).

Gaxiola et al. (2012) reported that the increase in the biomass input of plants submitted to the application of humic substances is certainly related to the improvement of the nutrient uptake by plants, as a consequence of the effect of humic substances on the cell membrane permeability. In addition to positively influencing the plant growth and nutrient availability, these substances can act directly on plants, facilitating the nutrient uptake, influencing the production of ATP and photosynthetic pigments and the activity of various enzymes (Rocha \& Rosa 2003, Canellas \& Santos 2005, Nardi et al. 2002, Mora et al. 2010, Vaccaro et al. 2015).

The application of humic acids in mangosteen crops may be a viable alternative to meet their high nutrient demand, inducing the plant development and consequently reducing the long nursery period of this fruit. Therefore, the present study aimed to evaluate the effect of the application of humic acids from vermicompost on the nutrient accumulation and content of photosynthetic pigments in mangosteen seedlings.

\section{MATERIAL AND METHODS}

The study was carried out in a greenhouse at the Universidade Estadual de Santa Cruz, in Ilhéus $\left(14^{\circ} 47^{\prime} 47.769^{\prime \prime} \mathrm{S}\right.$ and $\left.39^{\circ} 10^{\prime} 20.586^{\prime \prime} \mathrm{W}\right)$, Bahia state, Brazil, from May to November 2017. According to Köppen, the climate classification is Af, with $24.4{ }^{\circ} \mathrm{C}$ of average temperature. The experiment was conducted in a completely randomized design, where treatments were increasing humic acids doses $\left(0 \mathrm{mg} \mathrm{L}^{-1}, 2 \mathrm{mg} \mathrm{L}^{-1}, 20 \mathrm{mg} \mathrm{L}^{-1}, 40 \mathrm{mg} \mathrm{L}^{-1}\right.$ and $200 \mathrm{mg} \mathrm{L}^{-1}$ ), with seven replicates per treatment.

The humic acids were extracted using $0.1 \mathrm{~mol} \mathrm{~L}^{-1}$ of $\mathrm{NaOH}(1: 10, \mathrm{v}: \mathrm{v})$ under $\mathrm{N}_{2}$ atmosphere. After $4 \mathrm{~h}$ of stirring, the material was centrifuged $(3,000 \mathrm{~g} ; 20 \mathrm{~min})$ and acidified to $\mathrm{pH} 1.5$ with $6 \mathrm{~mol} \mathrm{~L}^{-1}$ of $\mathrm{HCl}$. The material was centrifuged again and the supernatant was discarded. The humic acids were solubilized, precipitated two more times and treated for $16 \mathrm{~h}$ with $\mathrm{HCl}: \mathrm{HF}$ diluted at 1:20 (v:v).
After centrifugation, they were titrated to $\mathrm{pH} 7.0$ with $0.1 \mathrm{~mol} \mathrm{~L}^{-1}$ of $\mathrm{KOH}$ and submitted to dialysis in membrane tubes with exclusion limit of 1,000 Da up to the point that the electrical conductivity value of the water was equal to that of the distilled water. The humic acids were then dried by lyophilization and stored (Canellas \& Olivares 2002).

The humic acids used were extracted from vermicompost of sugarcane filter cake containing $41 \%$ of $\mathrm{C}$ and $3.6 \%$ of $\mathrm{N}$ in its composition, and their solutions at the test concentrations of $0 \mathrm{mg} \mathrm{L}^{-1}$, $2 \mathrm{mg} \mathrm{L}^{-1}, 20 \mathrm{mg} \mathrm{L}^{-1}, 40 \mathrm{mg} \mathrm{L}^{-1}$ and $200 \mathrm{mg} \mathrm{L}^{-1}$ were prepared. With a micropipette, $0.1 \mathrm{M}$ of $\mathrm{NaOH}$ was added to aid in the resuspension of particles. The $\mathrm{pH}$ of the solutions was corrected to 7 .

Mangosteen seeds were initially removed from fruits, washed in running water and placed to germinate in trays filled with expanded vermiculite. To set up the experiment, seedlings with approximately $5 \mathrm{~cm}$ of height, at 30 days after germination, were selected. The germinated seeds were transplanted into containers with capacity of $5 \mathrm{dm}^{-3}$ filled with substrate enriched with Osmocote ${ }^{\circledR}$ slow-release fertilizer (25 g), Pgmix ${ }^{\circledR}(25 \mathrm{~g})$ and single superphosphate $(100 \mathrm{~g})$ for each $50 \mathrm{~L}$ of mixture. Humic acids doses were added in four $250 \mathrm{~mL}$ applications, what occurred at $0,60,120$ and 180 days after planting.

At 240 days after planting, three $1.5 \mathrm{~cm}$ diameter leaf discs were removed from the third complete leaf, for determining the photosynthetic pigment content (Hiscox \& Israelstam 1979). Leaf discs were immersed in $3.0 \mathrm{~mL}$ of dimethylsulfoxide (DMSO) and kept in the dark until they became translucent. Spectrophotometer readings were performed at $480 \mathrm{~nm}, 649 \mathrm{~nm}$ and $665 \mathrm{~nm}$ absorbance (A480, A649 and A665) and pigments were determined according to Wellburn (1994): [chlorophyll a] $\left(\mu \mathrm{g} \mathrm{mL}^{-1}\right)=12.19 \mathrm{~A} 665$ - $3.45 \mathrm{~A} 649 ;$ [chlorophyll b] $\left(\mu \mathrm{g} \mathrm{mL} \mathrm{mL}^{-1}\right)=21.99 \mathrm{~A} 649-5.32 \mathrm{~A} 665 ;$ [carotenoids] $\left(\mu \mathrm{g} \mathrm{mL} \mathrm{m}^{-1}\right)=(1000 \mathrm{~A} 480-2.14$ chlorophyll a -70.16 chlorophyll b)/220.

Plants were separated into leaf, stem and root and taken to a forced circulation oven, for $72 \mathrm{~h}$. Then, each sample was weighed in an analytical scale with accuracy of 0.01 . The nutrient concentrations were determined by nitric-perchloric and sulfuric digestion. P contents were determined by the molibidate method in a molecular absorption spectrophotometer; $\mathrm{K}$ by flame photometry; $\mathrm{Ca}, \mathrm{Mg}, \mathrm{Cu}, \mathrm{Fe}, \mathrm{Mn}$ and $\mathrm{Zn}$ by atomic absorption spectrometry; and $\mathrm{N}$ by the micro 
Kjeldahl method (Silva et al. 2009). The content of nutrients extracted per plant was obtained by the product between the nutrient concentration and the dry biomass of the respective vegetative organ. The content in the plant shoots was obtained by adding leaf and stem contents.

For the statistical analyses, the KomolgorovSmirnov test was performed to evaluate the normality of data distribution. Subsequently, analysis of variance was performed and, when significance was verified by the $\mathrm{F}$ test, regression analysis was performed as a function of humic acids doses, and the equation with significant effect was selected using the $\mathrm{F}$ test at $5 \%$ of probability and the smallest squared sum of the residue, i.e., the higher determination coefficient $\left(\mathrm{R}^{2}\right)$. For the determination of the influence of treatments on the study variables, multivariate analysis was also performed through the principal components analysis (PCA). All data were analyzed in the R (Ferreira et al. 2011) and SigmaPlot 12.0 softwares (SSI 2008).

\section{RESULTS AND DISCUSSION}

The analysis of variance showed a significant effect of the application of humic acids from vermicompost on the $\mathrm{N}, \mathrm{P}, \mathrm{K}, \mathrm{Ca}, \mathrm{Mg}$ and $\mathrm{S}$ contents in shoots and roots of mangosteen seedlings at 280 days after planting $(\mathrm{p}<0.05)$. The response curves to the application of humic acids doses showed curvilinear increments with quadratic rates for $\mathrm{N}$, $\mathrm{P}, \mathrm{K}, \mathrm{Ca}, \mathrm{Mg}$ and $\mathrm{S}$ contents in both the shoots and roots (Table 1). Due to this behavior, it was possible to verify that humic acids doses below $200 \mathrm{mg} \mathrm{L}^{-1}$ would provide higher $\mathrm{N}\left(147.89 \mathrm{mg} \mathrm{L}^{-1}\right)$, $\mathrm{P}\left(146.76 \mathrm{mgL}^{-1}\right), \mathrm{K}\left(147.97 \mathrm{mgL}^{-1}\right), \mathrm{Ca}\left(151.07 \mathrm{mgL}^{-1}\right)$, $\mathrm{Mg}$ (167.69 $\left.\mathrm{mg} \mathrm{L}^{-1}\right)$ and $\mathrm{S}\left(141,84 \mathrm{mg} \mathrm{L}^{-1}\right)$ for the shoot dry matter; and $\mathrm{N}\left(156.18 \mathrm{mg} \mathrm{L}^{-1}\right)$, $\mathrm{P}\left(142.10 \mathrm{mg} \mathrm{L}^{-1}\right), \mathrm{K}\left(132.62 \mathrm{mg} \mathrm{L}^{-1}\right), \mathrm{Ca}\left(31.03 \mathrm{mg} \mathrm{L}^{-1}\right)$ and $\mathrm{S}\left(154.41 \mathrm{mg} \mathrm{L}^{-1}\right)$ uptake for the root dry matter. In general, according to the regression analysis, doses around $150 \mathrm{mg} \mathrm{L}^{-1}$ provided a greater uptake of N, P, $\mathrm{K}, \mathrm{Ca}, \mathrm{Mg}$ and $\mathrm{S}$ nutrients by mangosteen seedlings. The effects of humic substances on nutrient uptake may be due to interferences in ion-specific chargers and changes in the charge balance of cytosol or in membrane fluidity and permeability, as a result of the plant $\mathrm{x}$ humic substance interaction (Rosa et al. 2009). The plant growth and nutrient uptake promoting action in plants by the application of humic acids occurs, in thesis, through suprastructural fragmentation by the release of organic acids by roots that acidify the rhizosphere, generating bioactive subunits potentially capable of altering the cell metabolism (Piccolo 2001, Façanha et al. 2002, Canellas et al. 2006).

Gaxiola et al. (2012) related the application of humic substances to the increase in the activity of the pyrophosphatase enzyme $\left(\mathrm{H}^{+}\right.$-PPase), which acts both in the nutrient uptake and plant development regulation. The positive effect of the increased $\mathrm{H}^{+}$-PPase activity is related to the electrochemical potential gradient, facilitating the influx of nutrients in favor of this transmembrane gradient (Taiz \& Zeiger 2017).

Table 1. Adjusted mathematical models, determination coefficient $\left(\mathrm{R}^{2}\right)$, optimum dose and Ymax for the $\mathrm{N}, \mathrm{P}, \mathrm{K}, \mathrm{Ca}, \mathrm{Mg}$ and $\mathrm{S}$ contents of mangosteen seedlings, at 240 days after planting, as a response to the application of humic acids extracted from vermicompost.

\begin{tabular}{llrrr}
\hline Variable & \multicolumn{1}{c}{ Equation } & $\mathrm{R}^{2}$ & Dose & Y \\
\hline $\mathrm{Nax}$ & Shoots $\left(\mathrm{mg} \mathrm{plant}^{-1}\right)$ & & & \\
$\mathrm{N}$ & $\hat{\mathrm{Y}}=228.80977744+1.98606379 \mathrm{x}-0.00671438 \mathrm{x}^{2}$ & 0.99 & 147.89 & 375.68 \\
$\mathrm{P}$ & $\hat{\mathrm{Y}}=23.7488353+0.30242522 \mathrm{x}-0.00103033 \mathrm{x}^{2}$ & 0.98 & 146.76 & 45.94 \\
$\mathrm{~K}$ & $\hat{\mathrm{Y}}=158.11829177+1.73455394 \mathrm{x}-0.00586088 \mathrm{x}^{2}$ & 0.99 & 147.97 & 286.45 \\
$\mathrm{Ca}$ & $\mathrm{Y}=5.02718155+0.58311187 \mathrm{x}-0.00192982 \mathrm{x}^{2}$ & 0.98 & 151.07 & 8.07 \\
$\mathrm{Mg}$ & $\hat{\mathrm{Y}}=34.60845981+0.28518221 \mathrm{x}-0.00085033 \mathrm{x}^{2}$ & 0.99 & 167.69 & 58.52 \\
$\mathrm{~S}$ & $\hat{\mathrm{Y}}=12.5297591+0.3272406 \mathrm{x}-0.0011535 \mathrm{x}^{2}$ & 0.99 & 141.84 & 35.74 \\
\hline & & & & \\
$\mathrm{N}$ & $\hat{\mathrm{Y}}=3.52750755+0.05395457 \mathrm{x}-0.00017273 \mathrm{x}^{2}$ & 0.98 & 156.18 & 7.74 \\
$\mathrm{P}$ & $\hat{\mathrm{Y}}=2.48328659+0.04101458 \mathrm{x}-0.00014432 \mathrm{x}^{2}$ & 0.92 & 142.10 & 5.40 \\
$\mathrm{~K}$ & $\hat{\mathrm{Y}}=2.84248393+0.05738841 \mathrm{x}-0.00021636 \mathrm{x}^{2}$ & 0.96 & 132.62 & 6.65 \\
$\mathrm{Ca}$ & $\hat{\mathrm{Y}}=1.04429049+0.01596652 \mathrm{x}-0.00005036 \mathrm{x}^{2}$ & 0.77 & 158.52 & 2.31 \\
$\mathrm{Mg}$ & $\hat{\mathrm{Y}}=4.44405401-0.00497322 \mathrm{x}+0.00008013 \mathrm{x}^{2}$ & 0.85 & 31.03 & 4.36 \\
$\mathrm{~S}$ & $\hat{\mathrm{Y}}=0.46516950+0.01081215 \mathrm{x}-0.00003501 \mathrm{x}^{2}$ & 0.98 & 154.41 & 1.29 \\
\hline
\end{tabular}


The positive response to the $\mathrm{N}$ uptake by $G$. mangostana plants may be attributed to the increased activation of the plasma membrane $\mathrm{H}^{+}$-ATPase enzyme (Zandonadi et al. 2007, Canellas \& Olivares 2014). Olivares et al. (2015) reported that the application of humic acids associated with growth promoting bacteria increases the $\mathrm{N}$ uptake by tomato plants, and attributed this result to glutamine, glutamate synthetase, aspartate, aminotransferase, nitrite and nitrate reductase, enzymes that are related to the uptake and assimilation of nutrients by plants (Vaccaro et al. 2009). Baldotto et al. (2009) observed that the application of humic acids during the acclimatization phase of pineapple also increases the $\mathrm{N}$ uptake by plants.

$\mathrm{P}$ is involved in a number of metabolic processes in plants, such as energy transfer (ATP). Viegas et al. (2018) reported that mangosteen seedlings developed on substrata poor in P present a reduced height, number of leaves and leaf area. In the present study, the application of humic acids extracted from vermicompost positively influenced the $\mathrm{P}$ uptake by plants. This result is probably related to the higher dry matter contribution of roots by plants, since $\mathrm{P}$ is an element that presents a reduced mobility in the substrate.

Regarding the macronutrient $\mathrm{K}$, as in this study, Costa et al. (2001) observed a higher uptake of this nutrient in treatments that received humic acids extracted from vermicompost. The authors attributed this effect to the change in the charge balance inside the cell, assuming that humic acids molecules with predominantly anionic character were absorbed, increasing the amount of negative charges in the cytoplasm, what favors the absorption of cations.

The $\mathrm{Ca}$ and $\mathrm{Mg}$ contents also increased with the application of humic acids from vermicompost, when compared to control plants. Baldotto et al. (2009) reported a positive effect of humic acids extracted from vermicompost on the $\mathrm{Ca}$ and $\mathrm{Mg}$ accumulation in 'Vitória' pineapple seedlings. Nikbakht et al. (2008) also reported a significant effect of humic acids on the $\mathrm{Ca}$ and $\mathrm{Mg}$ uptake in shoots of gerbera seedlings. In a different way, Pinheiro et al. (2010) observed decreases of linear and quadratic nature in the $\mathrm{Ca}$ and $\mathrm{Mg}$ accumulation, in response to doses of humic material and pure humic acid on eucalyptus seedlings.

$\mathrm{S}$ is the third nutrient that most limited the development of mangosteen seedlings, being only behind Fe and N (Viegas et al. 2018). Humic acids from vermicompost applied to mangosteen seedlings promoted a higher S uptake by plants. Maggioni et al. (1987) reported an increase in the $S$ uptake capacity of oat seedlings in response to biostimulant. Busato et al. (2016) also reported an increase in the $S$ uptake with the application of a commercial product based on humic acids in Callophyllum brasiliense seedlings.

The analysis of variance of the data showed a significant effect of the application of humic acids from vermicompost on the $\mathrm{Zn}$ and $\mathrm{Mn}$ contents in shoots and $\mathrm{Cu}, \mathrm{Fe}, \mathrm{Zn}$ and $\mathrm{Mn}$ in roots of mangosteen seedlings at 280 days after planting $(p<0.05)$. The response curves to the application of humic acids doses showed curvilinear increases with quadratic rates for the $\mathrm{Zn}$ and $\mathrm{Mn}$ contents in the shoot dry matter. For the root dry matter, the addition of humic acids was of a linear nature for the $\mathrm{Cu}$ content and quadratic for the Fe, $\mathrm{Zn}$ and $\mathrm{Mn}$ contents (Table 2). It was possible to verify that humic acids doses lower than $200 \mathrm{mg} \mathrm{L}^{-1}$ would provide a higher $\mathrm{Zn}\left(111.41 \mathrm{mg} \mathrm{L}^{-1}\right)$ and $\mathrm{Mn}$ uptake $\left(123.17 \mathrm{mg} \mathrm{L}^{-1}\right)$ for shoot dry mass and $\mathrm{Fe}\left(65.14 \mathrm{mg} \mathrm{L}^{-1}\right), \mathrm{Zn}\left(145.33 \mathrm{mg} \mathrm{L}^{-1}\right)$ and $\mathrm{Mn}$ (124.21 $\mathrm{mg} \mathrm{L}^{-1}$ ) uptake for root dry matter. This result can be explained by alterations in the root system architecture, evidenced by the increase of absorption sites and proportion of fine roots (Giro 2011), which are effectively responsible for the nutrient uptake.

The reduced initial growth of the root system, characterized by the absence of secondary roots and reduced lateral root development characteristic of mangosteen, may compromise the synthesis of metabolites important for plant growth and also impair the uptake of micronutrients such as Fe, $\mathrm{Zn}$ and Mn (Malavolta 2006, Marschner 2012, Carvalho 2014). In this sense, data indicate a direct influence of humic acids from vermicompost on the uptake of this nutrient by mangosteen seedlings.

Humic acids did not have a significant effect on the Fe uptake by the shoots of mangosteen seedlings, while the Fe content in roots presented the maximum uptake with $65.14 \mathrm{mg} \mathrm{L}^{-1}$ of humic acids. Moraes et al. (2006) reported a low efficiency of mangosteen seedlings in the Fe uptake, even with this nutrient present at a high concentration in the substrate used, indicating the necessity of Fe application in the nursery stage of this fruit tree. Busato et al. (2016) concluded that cationic micronutrients may be temporarily immobilized by complexes formed with 
Table 2. Adjusted mathematical models, determination coefficient $\left(\mathrm{R}^{2}\right)$, optimum dose and $\mathrm{Ymax}$ for $\mathrm{Cu}, \mathrm{Fe}, \mathrm{Zn}, \mathrm{Mn}$ contents of mangosteen seedlings at 240 days after planting, as a response to the application of humic acids extracted from vermicompost.

\begin{tabular}{|c|c|c|c|c|}
\hline Variable & Equation & $\mathrm{R}^{2}$ & Dose & $Y_{\max }$ \\
\hline \multicolumn{5}{|c|}{ Shoot $\left(\right.$ mg plant $\left.^{-1}\right)$} \\
\hline $\mathrm{Cu}$ & $\hat{Y}=$ not significant & - & - & - \\
\hline $\mathrm{Fe}$ & $\hat{Y}=$ not significant & - & - & - \\
\hline $\mathrm{Zn}$ & $\hat{Y}=0.18833204+0.00418447 x-0.00001878 x^{2}$ & 0.99 & 111.41 & 0.42 \\
\hline $\mathrm{Mn}$ & $\hat{Y}=1.89212225+0.02148077 x-0.0000872 x^{2}$ & 0.96 & 123.17 & 3.21 \\
\hline \multicolumn{5}{|c|}{ Root $\left(\mathrm{mg} \mathrm{plant}^{-1}\right)$} \\
\hline $\mathrm{Cu}$ & $\hat{Y}=0.04059024+0.00018905 x$ & 0.97 & - & - \\
\hline $\mathrm{Fe}$ & $\hat{Y}=5.81307808-0.02435693 x+0.00018695 x^{2}$ & 0.28 & 65.14 & 5.02 \\
\hline $\mathrm{Zn}$ & $\hat{Y}=0.0671869+0.00093009 x-0.0000032 x^{2}$ & 0.96 & 145.33 & 0.14 \\
\hline $\mathrm{Mn}$ & $\hat{Y}=0.17352411+0.00381318 x-0.00001535 x^{2}$ & 0.85 & 124.21 & 0.42 \\
\hline
\end{tabular}

bio-inputs, such as humic substances, what could have contributed to the results obtained in this study.

With respect to the $\mathrm{Zn}$ and $\mathrm{Mn}$ micronutrients, the application of humic acids in mangosteen seedlings increased their uptake as the humic acids dose applied increased. Lima et al. (2011) reported the influence of humic substances on the $\mathrm{Zn}$ and $\mathrm{Mn}$ concentrations in tomato plants. Pinheiro et al. (2010) concluded that the addition of humic acids promoted $\mathrm{Zn}$ and $\mathrm{Mn}$ accumulation in eucalyptus leaves and seedlings, if compared to the control treatment. Unlike tomato plants, Nikbakht et al. (2008) found that the $\mathrm{Zn}$ content in gerbera leaves decreased with the addition of $1,000 \mathrm{mg} \mathrm{L}^{-1}$ of humic acids. The positive effect of humic substances occurs due to complexation with these micronutrients, which may influence their uptake by roots due to their availability to the plant (Lima et al. 2011).

The concentration of nutrients in the substrate at the end of the experiment reduced considerably as the applied humic acids dose increased (Table 3 ). These values are the result of the effect of humic acids on the growth and nutrient uptake capacity of mangosteen seedlings.
According to the analysis of variance, the levels of chlorophyll a, chlorophyll b and carotenoids of mangosteen seedlings were significantly influenced by the humic acids doses. Regression analysis showed a positive linear response for chlorophyll a contents and of quadratic nature for chlorophyll $b$ contents (Figure 1). The carotenoid content presented reductions of linear nature as humic acids doses increased. Ferrara \& Brunetti (2008) reported increases in the chlorophyll content in response to the leaf humic acids application in 'Itália' grapes. The humic acids application in pineapple seedlings provided higher levels of photosynthetic pigments and a significant increase in the chlorophyll a/chlorophyll b ratio, when compared to the control (Baldotto et al. 2009). This behavior may be explained by the fact that these substances allow a more ordered distribution of thylakoids in chloroplasts, which favors the absorption of photons by chlorophylls, the transfer and conversion of NADPH and ATP light energy, what increases the photosynthesis in higher plants (Fan et al. 2014). The results can also be attributed to the action of humic acids from vermicompost, which activate the plasma membrane $\mathrm{H}^{+}$-ATPase enzyme,

Table 3. Chemical composition of the substrate before and after the experiment.

\begin{tabular}{|c|c|c|c|c|c|c|c|c|}
\hline \multirow{2}{*}{ Treatments } & $\mathrm{P}$ & $\mathrm{K}$ & $\mathrm{Ca}$ & $\mathrm{Mg}$ & $\mathrm{Cu}$ & $\mathrm{Mn}$ & $\mathrm{Fe}$ & $\mathrm{Zn}$ \\
\hline & \multicolumn{8}{|c|}{$\mathrm{mg} \mathrm{dm}^{-3}$} \\
\hline Before & 226.6 & 334 & 4.97 & 7.60 & 3.16 & 16.6 & 94.2 & 7.40 \\
\hline HA 0 & 216.2 & 333 & 4.83 & 5.75 & 2.99 & 15.2 & 52.0 & 6.46 \\
\hline HA 2 & 192.3 & 321 & 4.68 & 5.64 & 2.92 & 13.6 & 47.2 & 6.33 \\
\hline HA 20 & 165.0 & 311 & 4.47 & 5.54 & 2.78 & 13.3 & 44.6 & 6.05 \\
\hline HA 40 & 156.9 & 301 & 4.43 & 5.28 & 2.68 & 11.9 & 41.2 & 5.66 \\
\hline HA 200 & 142.1 & 296 & 4.23 & 5.15 & 2.12 & 11.0 & 40.3 & 5.52 \\
\hline
\end{tabular}

HA 0: humic acid at $0 \mathrm{mg} \mathrm{L}^{-1} ; \mathrm{HA}$ 2: humic acid at $2 \mathrm{mg} \mathrm{L}^{-1}$; $\mathrm{HA}$ 20: humic acid at $20 \mathrm{mg} \mathrm{L}^{-1}$; $\mathrm{HA}: 40$ humic acid at $40 \mathrm{mg} \mathrm{L}^{-1}$; $\mathrm{HA} 200$ : humic acid at $200 \mathrm{mg} \mathrm{L}^{-1}$. 


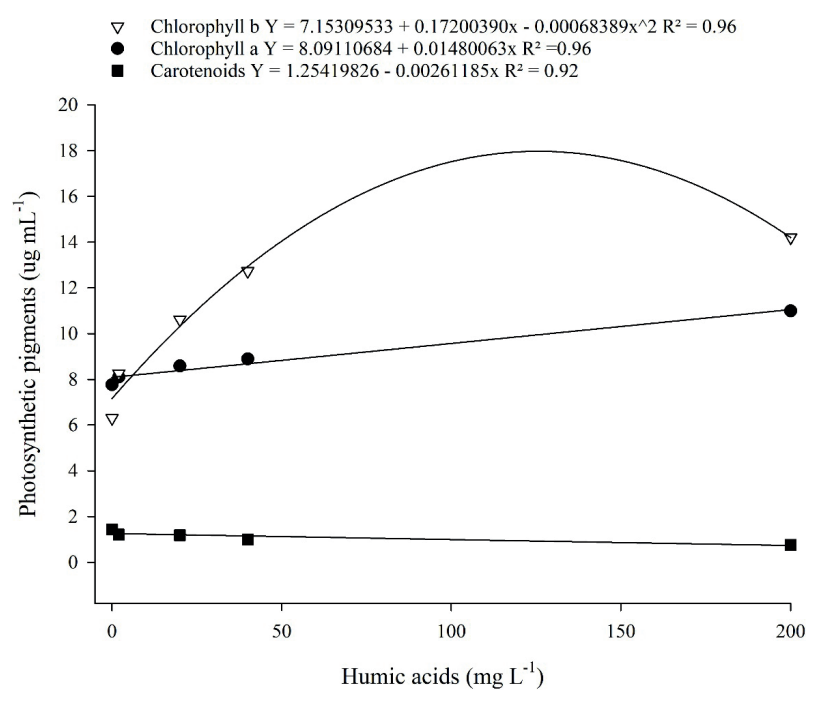

Figure 1. Regression analysis for photosynthetic pigments of mangosteen leaf in response to humic acids doses.

acidifying the rhizospheric region and increasing the $\mathrm{NH}_{4}{ }^{+}$and $\mathrm{NO}_{3}^{-}$uptake capacity, allowing a greater synthesis of chlorophyll molecules (Zandonadi et al. 2007, Canellas \& Olivares 2014).

Relationships among the nutrient content, photosynthetic pigments and humic acids doses can be visualized from the principal components analysis (PCA; Figure 2). Data variability was explained by $69.62 \%$ in the principal component 1 (PC1) and

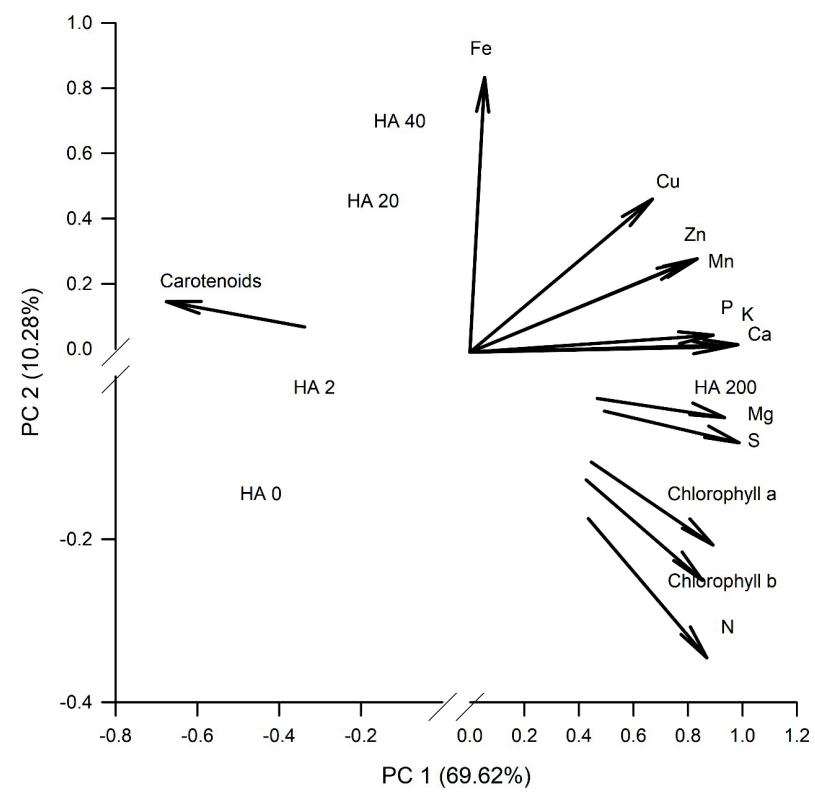

Figure 2. Principal components (PC) analysis for humic acid (HA) doses $\left(\mathrm{mg} \mathrm{L}^{-1}\right)$ applied to the substrate for mangosteen seedling cultivation.
$10.28 \%$ in the principal component 2 (PC2), totaling $79.9 \%$ of total data variability. Values are consistent with the criterion proposed by Sneath \& Sokal (1973), in which the principal components explain more than $70 \%$ of the data variability. Humic acids doses were separated into three response groups, the first group consisting of $\mathrm{AH} 0$ and $\mathrm{AH} 2$, the second group consisting of AH20 and AH40 and, finally, AH200, which most influenced the nutrient content extracted per plant and the chlorophyll a and chlorophyll $\mathrm{b}$ contents, being among the most adequate doses tested for the nutrition of mangosteen seedlings.

In relation to the PCA, it was observed that, in the $\mathrm{PC} 1$, correlations were positive for all nutrients, chlorophyll a and chlorophyll $\mathrm{b}$, while a negative correlation was verified for the carotenoid content (Table 4). In this component, the lowest correlation was observed for the Fe micronutrient, which, in the PC2, presented the highest correlation coefficient. According to Marschner (2012), the excess of the other cationic micronutrients $(\mathrm{Cu}, \mathrm{Zn}$ and $\mathrm{Mn})$ affects the Fe uptake and translocation by competitive inhibition among cations for presenting a similar ionic radius.

The response curves to the application of humic acids doses in the substrate for the production of mangosteen seedlings presented a quadratic variation, evidencing a dose-dependent effect of humic acids on the nutrient uptake by plants. The results indicate the possibility of the use of humic acids extracted from vermicompost during the formation of mangosteen seedlings, based on the greatest nutrient uptake verified in the plants.

Table 4. Pearson's correlation coefficients among the principal component (PC) scores for nutrient content and photosynthetic pigments of mangosteen seedlings.

\begin{tabular}{lcc}
\hline \multicolumn{1}{c}{ Variable } & PC1 & PC2 \\
\hline $\mathrm{N}$ & 0.87 & -0.34 \\
$\mathrm{P}$ & 0.89 & 0.05 \\
$\mathrm{~K}$ & 0.99 & 0.02 \\
$\mathrm{Ca}$ & 0.98 & 0.02 \\
$\mathrm{Mg}$ & 0.93 & -0.05 \\
$\mathrm{~S}$ & 0.99 & -0.08 \\
$\mathrm{Cu}$ & 0.67 & 0.47 \\
$\mathrm{Fe}$ & 0.05 & 0.84 \\
$\mathrm{Zn}$ & 0.81 & 0.28 \\
$\mathrm{Mn}$ & 0.83 & 0.29 \\
$\mathrm{Chlorophyll} \mathrm{a}$ & 0.85 & -0.25 \\
Chlorophyll b & 0.89 & -0.20 \\
Carotenoids & -0.68 & 0.16 \\
\hline
\end{tabular}




\section{CONCLUSIONS}

1. Humic acids extracted from vermicompost positively influence the uptake of the $\mathrm{N}, \mathrm{P}, \mathrm{K}, \mathrm{Ca}$, $\mathrm{Mg}, \mathrm{S}, \mathrm{Fe}, \mathrm{Zn}, \mathrm{Cu}$ and $\mathrm{Mn}$ nutrients;

2. Humic acids increase the content of the photosynthetic pigments chlorophyll a and chlorophyll b;

3. The dose of $150 \mathrm{mg} \mathrm{L}^{-1}$ is recommended to obtain the maximum nutrient uptake in mangosteen seedlings.

\section{ACKNOWLEDGMENTS}

The authors would like to thank Fabio Lopes Olivares and Luciano Pasqualoto Canellas, from the Nucleus for the Development of Biological Inputs for Agriculture (NUDIBA/UENF), for providing materials and technical recommendations. This study was partly funded by the Coordenação de Aperfeiçoamento de Pessoal de Nível Superior - Brazil (Capes) - Financing Code 001.

\section{REFERENCES}

BALDOTTO, L. E. B. et al. Desempenho do abacaxizeiro 'Vitória' em resposta à aplicação de ácidos húmicos durante a aclimatação. Revista Brasileira de Ciência do Solo, v. 33, n. 1, p. 979-990, 2009.

BUSATO, J. G. et al. Efeito do extrato húmico solúvel em água e biofertilizante sobre o desenvolvimento de mudas de Callophyllum brasiliense. Pesquisa Florestal Brasileira, v. 36, n. 86, p. 161-168, 2016.

CANELLAS, L. C.; SANTOS, G. A. Humosfera: tratado preliminar sobre a química das substâncias húmicas. Campos dos Goytacazes: CCTA/UENF, 2005.

CANELLAS, L. P. et al. Efeitos fisiológicos de substâncias húmicas: o estímulo às $\mathrm{H}^{+}$-ATPases. In: FERNANDES, M. S. (Org.). Nutrição mineral de plantas. Viçosa, MG: Sociedade Brasileira de Ciência do Solo, 2006. p. 175200.

CANELLAS, L. P.; OLIVARES, F. L. Humic acids isolated from earthworm compost enhance root elongation, lateral root emergence, and plasma membrane $\mathrm{H}^{+}$-ATPase activity in maize roots. Plant Physiology, v. 130, n. 4, p. 19511957, 2002.

CANELLAS, L. P.; OLIVARES, F. L. Physiological responses to humic substances as plant growth promoter. Chemical and Biological Technologies in Agriculture, v. 1, n. 3, p. 3-14, 2014.
CARVALHO, J. E. U. de. Mangostanzeiro: botânica, propagação, cultivo e utilização. Revista Brasileira de Fruticultura, v. 36, n. 1, p. 148-155, 2014.

COSTA, C. N. Efeito das substâncias húmicas no desenvolvimento radicular da cebola, Allium cepa L., e na cinética de absorção de fósforo e potássio. 2001. 51 f. Dissertação (Mestrado em Agronomia) - Universidade Federal de Pelotas, Pelotas, 2001.

FAÇANHA, A. R. et al. Bioatividade de ácidos húmicos: efeito sobre o desenvolvimento radicular e sobre a bomba de prótons da membrana plasmática. Pesquisa Agropecuária Brasileira, v. 37, n. 9, p. 1301-1310, 2002.

FAN, H. et al. Effects of humic acid derived from sediments on growth, photosynthesis and chloroplast ultrastructure in chrysanthemum. Scientia Horticulturae, v. 177, n. 1, p. 118-123, 2014.

FERRARA, G.; BRUNETTI, G. Influence of foliar applications of humic acids on yield and fruit quality of table grape cv. Itália. Journal International des Sciences de La Vigne Et Du Vin, v. 42, n. 2, p. 79-87, 2008.

FERREIRA, E. B.; CAVALCANTI, P. P.; NOGUEIRA, D. A. Experimental designs: um pacote $\mathrm{R}$ para análise de experimentos. Revista de Estatística da UFOP, v. 1, n. 1, p. 1-9, 2011.

GAXIOLA, R. A. et al. Genetic manipulation of a vacuolar $\mathrm{H}^{+}$-PPase: from salt tolerance to yield enhancement under phosphorus-deficient soils. Plant Physiology, v. 159, n. 1, p. 3-11, 2012.

GIRO, V. B. Crescimento do abacaxizeiro 'Vitória' em resposta à aplicação de vermicomposto, ácidos húmicos e bactérias promotoras de crescimento. 2011. 93 f. Dissertação (Mestrado em Produção Vegetal) Universidade Estadual do Norte Fluminense, Campos dos Goytacazes, 2011.

HISCOX, J. D.; ISRAELSTAM, G. F. A method for the extraction of chlorophyll from leaf tissue without maceration. Canadian Journal of Botany, v. 57, n. 12, p. 1332-1334, 1979.

LIMA, A. A. et al. Concentração foliar de nutrientes e produtividade de tomateiro cultivado sob diferentes substratos e doses de ácidos húmicos. Horticultura Brasileira, v. 29, n. 1, p. 63-69, 2011.

MAGGIONI, A. et al. Action of soil humic matter on plant roots: stimulation of ion uptake and effects on $\left(\mathrm{Mg}^{2++}\right.$ $\mathrm{K}^{+}$) ATPase activity. Science of the Total Environment, v. 62, n. 1, p. 355-36, 1987.

MALAVOLTA, E. Manual de nutrição mineral de plantas. Piracicaba: Agronômica Ceres, 2006. 
MARSCHNER, H. Mineral nutrition of higher plants. 3. ed. London: Elsevier, 2012.

MORA, V. et al. Action of humic acid on promotion of cucumber shoot growth involves nitrate-related changes associated with the root-to-shoot distribution of cytokinins, polyamines and mineral nutrients. Journal of Plant Physiology, v. 167, n. 8, p. 633-642, 2010.

MORAES, L. A. C.; GARCIA, T. B.; MOREIRA, A. Nutritional limitations of mangosteen seedlings. Pesquisa Agropecuária Brasileira, v. 41, n. 7, p. 1205-1208, 2006.

NARDI, S. et al. Physiological effects of humic substances on higher plants. Soil Biology and Biochemistry, v. 34, n. 11, p. 1527-1536, 2002.

NIKBAKHT, A. et al. Effect of humic acid on plant growth, nutrient uptake, and postharvest life of gerbera. Journal of Plant Nutrition, v. 31, n. 1, p. 2155-2167, 2008.

OLIVARES, F. L. et al. Substrate biofortification in combination with foliar sprays of plant growth promoting bacteria and humic substances boosts production of organic tomatoes. Scientia Horticulturae, v. 183, n. 1 p. 100-108, 2015.

PICCOLO, A. The supramolecular structure of humic substances. Soil Science, v. 166, n. 11, p. 810-832, 2001.

PINHEIRO, G. L.; SILVA, C. A.; FURTINI NETO, A. E. Crescimento e nutrição de clone de eucalipto em resposta à aplicação de concentrações de c-ácido húmico. Revista Brasileira de Ciência do Solo, v. 34, n. 4, p. 1217-1229, 2010.

ROCHA, J. C.; ROSA, A. H. Substâncias húmicas aquáticas: interações com espécies metálicas. São Paulo: Ed. Unesp, 2003.

ROSA, C. M. et al. Effect of humic-like substances on potassium uptake kinetics, plant growth and nutrient concentration in Phaseolus vulgaris L. Revista Brasileira de Ciência do Solo, v. 33, n. 4, p. 959-967, 2009.

SACRAMENTO, C. K. do et al. Cultivo de mangostão no Brasil. Revista Brasileira de Fruticultura, v. 29, n. 1, p. 195-203, 2007.
SACRAMENTO, C. K. et al. Mangostão. In: SANTOSSEREJO, J. A. dos; DANTAS, J. L. L.; COELHO, Y. da S. Fruticultura tropical: espécies regionais e exóticas. Brasília, DF: Embrapa Informação Tecnológica, 2009. p. 39-362.

SILVA, F. C. da (Ed.). Manual de análises químicas de solos, plantas e fertilizantes. Brasília, DF: Embrapa, 2009.

SNEATH, P. H.; SOKAL, R. R. Numerical taxonomy: the principles and practice of numerical classification. San Francisco: W. H. Freeman, 1973.

SYSTAT SOFTWARE INC (SSI). SigmaPlot for Windows: version 11.0. San Jose: Systat Software Inc., 2008.

TAIZ, L.; ZEIGER, E. Fisiologia vegetal. 6. ed. Porto Alegre: Artmed, 2017.

VACCARO, S. et al. Effect of a compost and its watersoluble fractions on key enzymes of nitrogen metabolism in maize seedlings. Journal of Agricultural and Food Chemistry, v. 57, n. 23, p. 11267-11276, 2009.

VACCARO, S. et al. Humic substances stimulate maize nitrogen assimilation and amino acid metabolism at physiological and molecular level. Chemical and Biological Technologies in Agriculture, v. 2, n. 1, p. 2-5, 2015

VIEGAS, I. D. J. M. et al. Growth and visual symptoms of nutrients deficiency in mangosteens (Garcinia mangostana L.). American Journal of Plant Sciences, v. 9, n. 9, p. 1014$1028,2018$.

WELLBURN, A. R. The spectral determination of chlorophylls a and $\mathrm{b}$, as well as total carotenoids, using various solvents with spectrophotometers of different resolution. Journal of Plant Physiology, v. 144, n. 3, p. 307-313, 1994.

ZANDONADI, D. B.; CANELLAS, L. P.; FAÇANHA, A. R. Indolacetic and humic acids induce lateral root development through a concerted plasmalemma and tonoplast $\mathrm{H}^{+}$pumps activation. Planta, v. 225 , n. 6 , p. 1583-1595, 2007. 